UDC 332.1

LBC 65.049(2)

\title{
FOOD SECURITY IN THE VOLGOGRAD REGION AND DIRECTIONS OF ITS IMPROVEMENT
}

\author{
Maksim P. Pridachuk \\ Volgograd Institute of Management - Branch of Russian Presidential Academy of National Economy \\ and Public Administration, Volgograd, Russian Federation \\ Aleksandr P. Almosov \\ Volgograd Institute of Management - Branch of Russian Presidential Academy of National Economy \\ and Public Administration, Volgograd, Russian Federation \\ Yuliya V. Brekhova \\ Volgograd Institute of Management - Branch of Russian Presidential Academy of National Economy \\ and Public Administration, Volgograd, Russian Federation
}

\begin{abstract}
Ensuring food security at the national and regional levels is considered as the main factor of economic safety of the country and improvement of the level and life quality of the population.

The Volgograd region is an industrial-agrarian region, $78 \%$ of which is represented by agricultural lands. The analysis of food security shows that over the past five years a greater number of agricultural products grew in volume production. The level of food security in terms of food self-sufficiency in most cases is at a high level. The Volgograd region provides such products as cereal, potatoes, vegetables, melon food, eggs.

A significant problem for the region is the lack of availability of meat products. Consumption of some foodstuff by the population of the Volgograd region has decreased. According to the analysis of food security of the Volgograd region, it can be concluded that during 2011-2015 the region was characterized by a high level of it.

Among all kinds of products that are produced at the territory of the Volgograd region, meat products have the worst dynamics in terms of production volumes. The authors recommend to create the meat cluster which would include agricultural enterprises, educational and research institutions, business entities and infrastructure objects. The purpose of creating this cluster consists in the cooperation between its elements and the reduction of effectiveness through innovation in production.

Key words: economic security, food security, food self-sufficiency, norms of food consumption, meat cluster.

УДК 332.1

ББК 65.049(2)

ПРОДОВОЛЬСТВЕННАЯ БЕЗОПАСНОСТЬ ВОЛГОГРАДСКОЙ ОБЛАСТИ И НАПРАВЛЕНИЯ ЕЕ ПОВЫШЕНИЯ
\end{abstract}

\author{
Максим Петрович Придачук \\ Волгоградский институт управления - филиала РАНХиГС, г. Волгоград, Российская Федерация \\ Александр Павлович Алмосов \\ Волгоградский институт управления - филиал РАНХиГС, г. Волгоград, Российская Федерация \\ Юлия Викторовна Брехова \\ Волгоградский институт управления - филиал РАНХиГС, г. Волгоград, Российская Федерация
}


Аннотация. Обеспечение продовольственной безопасности на национальном и региональном уровнях рассматривается как главный фактор экономической безопасности страны и повышения уровня и качества жизни населения.

Волгоградская область является индустриально-аграрным регионом, в результате чего около 78 \% его общей площади - земли сельскохозяйственного назначения. Анализ продовольственной безопасности показывает, что за последние пять лет большее число видов сельскохозяйственной продукции выросло в объемах производства. Уровень продовольственной безопасности по показателю продовольственной самообеспеченности в большинстве случаев является высоким. Волгоградская область обеспечивает себя такими видами продукции, как зерновые культуры, картофель, овощи, бахчи продовольственные, яйца.

Вместе с тем объемы потребления ряда продуктов питания населением Волгоградской области снизились. Среди всех видов продуктов, которые производятся на территории Волгоградской области, наихудшей динамикой по объемам производства обладает мясная продукция. В качестве рекомендации предлагается создание мясного кластера, который будет включать в себя сельскохозяйственные предприятия, образовательные и научно-исследовательские учреждения, предприятия и организации инфраструктуры. Целью создания кластера является развитие кооперации между его элементами и снижение эффективности деятельности за счет инноваций в производстве.

Ключевые слова: экономическая безопасность, продовольственная безопасность, продовольственная самообеспеченность, нормы потребления пищевых продуктов, мясной кластер.

Продовольственная безопасность является одной из главных компонент национальной безопасности государства. Именно поэтому в России, равно как и в большинстве других стран мира, обеспечение данного вида безопасности является приоритетным направлением государственной политики [2]. Решение указанной задачи реализуется на всех уровнях государственного управления: национальном, региональном и местном. Оценка и обеспечение достаточного уровня продовольственной безопасности территории характерны и для администрации Волгоградской области.

Выгодное экономико-географическое положение региона, развитая транспортная сеть и наличие природных ресурсов обеспечивают Волгоградской области высокий потенциал производственного развития. Вместе с тем Волгоградская область является индустриально-аграрным регионом, в котором земли сельскохозяйственного назначения составляют до 78 \% общей площади.

Для расчета уровня продовольственной самообеспеченности региона рассмотрим динамику трех показателей: фактические объемы производства основных видов сельскохозяйственной продукции в регионе за отчетный период; численность населения, проживающего на территории региона; количество продовольствия, необходимого для данного региона в соответствии с установленными рациональными нормами потребления [1; 3].
Фактические объемы производства основных видов сельскохозяйственной продукции на территории Волгоградской области в 2011-2015 гг. представим в таблице 1.

В соответствии с данными таблицы 1 значительная часть видов сельскохозяйственной продукции выросла в объемах производства: зерновые культуры на 9,20 \% (несмотря на существенный спад в 2012 и 2015 гг.), картофель на 13,34\%, овощи на $6,96 \%$, мясо овец и коз на 23,08 \%, мясо птицы на 42,99 \%. Для расчета необходимых объемов производства продовольственных товаров на территории Волгоградской области приведем динамику численности населения региона в 2011-2015 гг. (см. рис. 1), а также нормы потребления сельскохозяйственной продукции в соответствии с Приказом Министерства здравоохранения РФ № 614 от 19 августа 2016 г. «Об утверждении рекомендаций по рациональным нормам потребления пищевых продуктов, отвечающих современным требованиям здорового питания» (см. табл. 2).

В течение последних пяти лет численность населения региона стабильно снижалась и к концу 2015 г. достигла значения 2557,4 тыс. человек.

Данные таблицы 2 используем для расчета объемов производства продовольствия, необходимого для Волгоградской области в соответствии с установленными рациональными нормами потребления (см. табл. 3). 
Объемы производства основных видов сельскохозяйственной продукции на территории Волгоградской области в 2011-2015 гг.

\begin{tabular}{|c|c|c|c|c|c|c|c|c|c|c|}
\hline \multirow{2}{*}{ Показатели } & 2011 & 2012 & 2013 & 2014 & 2015 & $\begin{array}{l}2012 / \\
2011\end{array}$ & $\begin{array}{l}2013 / \\
2012\end{array}$ & $\begin{array}{l}2014 / \\
2013\end{array}$ & $\begin{array}{l}2015 / \\
2014\end{array}$ & $\begin{array}{l}2015 / \\
2011\end{array}$ \\
\hline & \multicolumn{5}{|c|}{ Абсолютное значение } & \multicolumn{5}{|c|}{ Динамика, \% } \\
\hline $\begin{array}{l}\text { Зерновые куль- } \\
\text { туры, тыс. т }\end{array}$ & 2674,9 & 2422,7 & 3088,5 & 3913,8 & 2920,9 & 90,57 & 127,48 & 126,72 & 74,63 & 109,20 \\
\hline Картофель, тыс. т & 377,90 & 401,10 & 400,10 & 399,70 & 428,30 & 106,14 & 99,75 & 99,90 & 107,16 & 113,34 \\
\hline Овощи, тыс. т & 840,60 & 829,10 & 797,80 & 801,30 & 899,10 & 98,63 & 96,22 & 100,44 & 112,21 & 106,96 \\
\hline $\begin{array}{l}\text { Бахчи продо- } \\
\text { вольственные, } \\
\text { тыс. т }\end{array}$ & 275,80 & 228,10 & 217,20 & 249,50 & 228,50 & 82,70 & 95,22 & 114,87 & 91,58 & 82,85 \\
\hline $\begin{array}{l}\text { Скот и птица на } \\
\text { убой (в убойном } \\
\text { весе), тыс. т }\end{array}$ & 147,30 & 145,60 & 142,50 & 151,00 & 143,30 & 98,85 & 97,87 & 105,96 & 94,90 & 97,28 \\
\hline $\begin{array}{l}\text { Крупный рога- } \\
\text { тый скот, тыс. т }\end{array}$ & 37,20 & 38,20 & 39,00 & 38,80 & 36,70 & 102,69 & 102,09 & 99,49 & 94,59 & 98,66 \\
\hline Свиньи, тыс. т & 59,50 & 53,40 & 46,90 & 40,00 & 35,80 & 89,75 & 87,83 & 85,29 & 89,50 & 60,17 \\
\hline $\begin{array}{l}\text { Овцы и козы, } \\
\text { тыс. т }\end{array}$ & 6,50 & 6,80 & 7,80 & 7,90 & 8,00 & 104,62 & 114,71 & 101,28 & 101,27 & 123,08 \\
\hline Птица, тыс. т & 43,50 & 46,60 & 48,20 & 63,60 & 62,20 & 107,13 & 103,43 & 131,95 & 97,80 & 142,99 \\
\hline Молоко, тыс. т & 509,30 & 521,20 & 529,60 & 523,00 & 510,10 & 102,34 & 101,61 & 98,75 & 97,53 & 100,16 \\
\hline Яйца, млн шт. & 757,40 & 778,30 & 734,00 & 754,80 & 760,80 & 102,76 & 94,31 & 102,83 & 100,79 & 100,45 \\
\hline $\begin{array}{l}\text { Рыба живая, } \\
\text { свежая и охлаж- } \\
\text { денная, т }\end{array}$ & 8530,1 & 9646,3 & 7565,2 & 4602,3 & 4534,3 & 113,09 & 78,43 & 60,84 & 98,52 & 53,16 \\
\hline
\end{tabular}

Примечание. Составлено авторами по данным Федеральной службы государственной статистики. URL: http://www.gks.ru/bgd/regl/b16_14p/Main.htm.

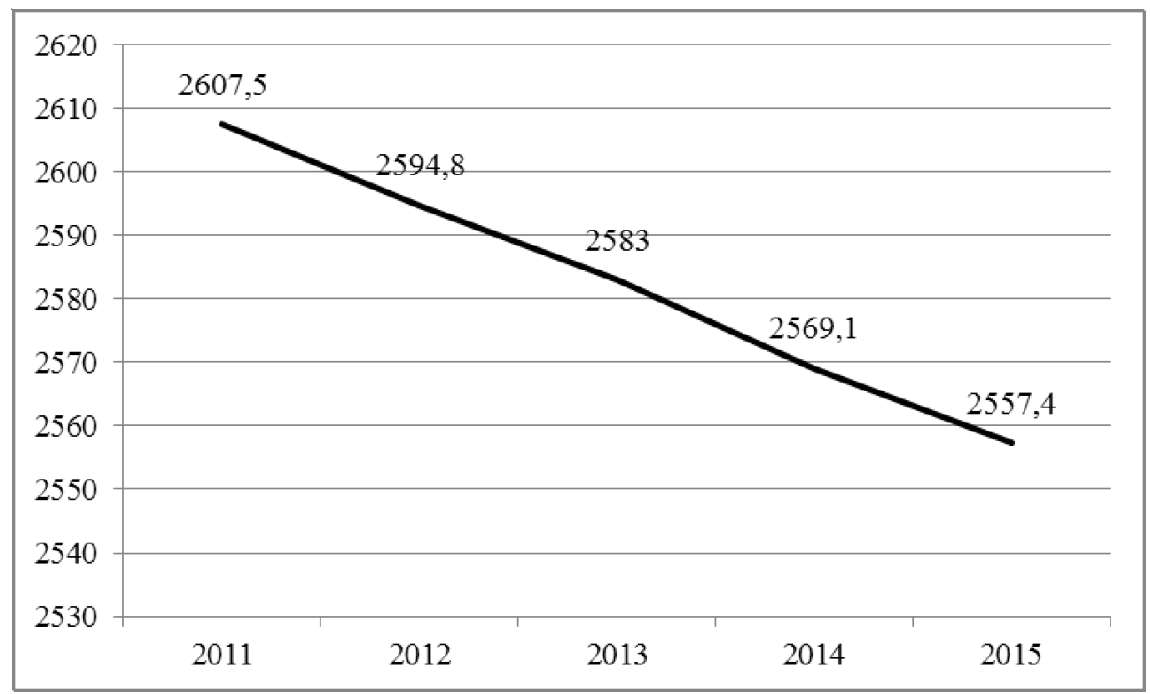

Рис. 1. Динамика численности населения Волгоградской области в 2011-2015 гг., тыс. чел.

Примечание. Составлено авторами по данным Федеральной службы государственной статистики. URL: http://www.gks.ru/bgd/regl/b16_14p/Main.htm. 
М.П. Придачук, А.П. Алмосов, Ю.В. Брехова. Продовольственная безопасность Волгоградской области

Таблийа 2

Нормы потребления сельскохозяйственной продукции

в соответствии с Приказом Министерства здравоохранения РФ № 614

от 19 августа 2016 г. «Об утверждении рекомендаций

по рациональным нормам потребления

пищевых продуктов, отвечающих современным требованиям здорового питания»

\begin{tabular}{|l|c|c|}
\hline \multicolumn{1}{|c|}{ Показатель } & Единица измерения & Норматив \\
\hline Хлебные продукты & кг/чел. & 96 \\
\hline Картофель & кг/чел. & 90 \\
\hline Овощи & кг/чел. & 125 \\
\hline Бахчевые & кг/чел. & 15 \\
\hline Говядина & кг/чел. & 20 \\
\hline Баранина & кг/чел. & 3 \\
\hline Свинина & кг/чел. & 18 \\
\hline Птица & кг/чел. & 31 \\
\hline Рыбопродукты & кг/чел. & 22 \\
\hline Молоко & кг/чел. & 325 \\
\hline Яйца & шт. & 260 \\
\hline
\end{tabular}

Примечание. Составлено авторами по данным Федеральной службы государственной статистики. URL: http://www.gks.ru/bgd/regl/b16_14p/Main.htm.

Объемы производства продовольствия, необходимого для Волгоградской области в соответствии с установленными рациональными нормами потребления в 2011-2015 гг.

\begin{tabular}{|l|c|c|c|c|c|c|}
\hline \multicolumn{1}{|c|}{ Показатель } & $\begin{array}{c}\text { Единица } \\
\text { измерения }\end{array}$ & 2011 & 2012 & 2013 & 2014 & 2015 \\
\hline Зерновые культуры & тыс. т & 250,32 & 249,1008 & 247,968 & 246,6336 & 245,5104 \\
\hline Картофель & тыс. т & 234,675 & 233,532 & 232,47 & 231,219 & 230,166 \\
\hline Овощи & тыс. т & 325,9375 & 324,35 & 322,875 & 321,1375 & 319,675 \\
\hline Бахчи продовольственные & тыс. т & 4,137 & 3,4215 & 3,258 & 3,7425 & 3,4275 \\
\hline $\begin{array}{l}\text { Скот и птица на убой } \\
\text { (в убойном весе) }\end{array}$ & тыс. т & 187,74 & 186,8256 & 185,976 & 184,9752 & 184,1328 \\
\hline Крупный рогатый скот & тыс. т & 52,15 & 51,896 & 51,66 & 51,382 & 51,148 \\
\hline Свиньи & тыс. т & 46,935 & 46,7064 & 46,494 & 46,2438 & 46,0332 \\
\hline Овцы и козы & тыс. т & 7,8225 & 7,7844 & 7,749 & 7,7073 & 7,6722 \\
\hline Птица & тыс. т & 80,8325 & 80,4388 & 80,073 & 79,6421 & 79,2794 \\
\hline Молоко & тыс. т & 847,4375 & 843,31 & 839,475 & 834,9575 & 831,155 \\
\hline Яйца & млн шт. & 677,95 & 674,648 & 671,58 & 667,966 & 664,924 \\
\hline $\begin{array}{l}\text { Рыба живая, свежая и ох- } \\
\text { лажденная }\end{array}$ & т & 57365 & 57085,6 & 56826 & 56520,2 & 56262,8 \\
\hline
\end{tabular}

Примечание. Составлено авторами по данным Федеральной службы государственной статистики. URL: http://www.gks.ru/bgd/regl/b16_14p/Main.htm.

Согласно таблице 3, объем производства продовольствия, необходимого для населения Волгоградской области, постоянно снижался. Такая ситуация была связана с сокращением численности населения региона. Уровень продовольственной само- обеспеченности региона рассчитаем в таблице 4.

Согласно данным таблицы 4, уровень продовольственной безопасности по показателю продовольственной самообеспеченности в большинстве случаев находился на вы- 
соком уровне. Волгоградская область обеспечивает себя такими видами продукции, как зерновые культуры, картофель, овощи, бахчи продовольственные, яйца. Существенной проблемой для региона является недостаточная обеспеченность мясной продукцией. Так, если птицей и мясом крупного рогатого скота область себя никогда не обеспечивала, то начиная с 2014 г. регион перестал себя обеспечивать и свининой. В целом уровень продовольственной безопасности региона по оцениваемому показателю находится на высоком уровне и составляет 2,71 балла.
На следующем шаге рассчитаем степень удовлетворения физиологических потребностей населения в продовольствии. Для расчета указанного показателя необходимо в дополнение к таблице 2 определить объемы реального потребления продуктов питания населением Волгоградской области в 20112015 гг. (табл. 5).

Согласно данным таблицы 5, объемы потребления ряда продуктов питания населением Волгоградской области снизились. В частности, жители региона снизили потребление зерновых культур, картофеля и молока. В то же время объемы потребления овощей и яиц

Уровень продовольственной самообеспеченности Волгоградской области в 2011-2015 гг. и оценка среднего уровня по данному показателю

\begin{tabular}{|l|c|c|c|c|c|c|c|c|c|c|c|}
\hline \multirow{2}{*}{ Показатель } & 2011 & 2012 & 2013 & 2014 & 2015 & 2011 & 2012 & 2013 & 2014 & 2015 \\
\cline { 2 - 13 } & \multicolumn{9}{|c|}{ Коэффициент } & \multicolumn{5}{c|}{ Баллы } \\
\hline Зерновые культуры & 10,69 & 9,73 & 12,46 & 15,87 & 11,90 & 3,00 & 3,00 & 3,00 & 3,00 & 3,00 \\
\hline Картофель & 1,61 & 1,72 & 1,72 & 1,73 & 1,86 & 3,00 & 3,00 & 3,00 & 3,00 & 3,00 \\
\hline Овощи & 2,58 & 2,56 & 2,47 & 2,50 & 2,81 & 3,00 & 3,00 & 3,00 & 3,00 & 3,00 \\
\hline Бахчи продовольственные & 66,67 & 66,67 & 66,67 & 66,67 & 66,67 & 3,00 & 3,00 & 3,00 & 3,00 & 3,00 \\
\hline $\begin{array}{l}\text { Скот и птица на убой } \\
\text { в убойном весе) }\end{array}$ & 0,78 & 0,78 & 0,77 & 0,82 & 0,78 & 2,00 & 2,00 & 2,00 & 2,00 & 2,00 \\
\hline Крупный рогатый скот & 0,71 & 0,74 & 0,75 & 0,76 & 0,72 & 2,00 & 2,00 & 2,00 & 2,00 & 2,00 \\
\hline Свиньи & 1,27 & 1,14 & 1,01 & 0,86 & 0,78 & 3,00 & 3,00 & 3,00 & 2,00 & 2,00 \\
\hline Овцы и козы & 0,83 & 0,87 & 1,01 & 1,03 & 1,04 & 2,00 & 2,00 & 3,00 & 3,00 & 3,00 \\
\hline Птица & 0,54 & 0,58 & 0,60 & 0,80 & 0,78 & 1,00 & 2,00 & 2,00 & 2,00 & 2,00 \\
\hline Молоко & 0,60 & 0,62 & 0,63 & 0,63 & 0,61 & 2,00 & 2,00 & 2,00 & 2,00 & 2,00 \\
\hline Яйца & 1,12 & 1,15 & 1,09 & 1,13 & 1,14 & 3,00 & 3,00 & 3,00 & 3,00 & 3,00 \\
\hline Средний балл по 11 показателям & \multicolumn{70}{|c|}{} & & & 2,71 & 2,71 & 2,71 & 2,71 & 2,71 \\
\hline
\end{tabular}

Примечание. Составлено авторами по данным Федеральной службы государственной статистики. URL: http://www.gks.ru/bgd/regl/b16_14p/Main.htm.

Таблица 5

Объемы реального потребления продуктов питания населением Волгоградской области в 2011-2015 гг.

\begin{tabular}{|l|c|c|c|c|c|c|c|c|c|c|c|}
\hline \multirow{2}{*}{ Показатель } & 2011 & 2012 & 2013 & 2014 & 2015 & $\begin{array}{c}2012 / \\
2011\end{array}$ & $\begin{array}{c}2013 / \\
2012\end{array}$ & $\begin{array}{c}2014 / \\
2013\end{array}$ & $\begin{array}{c}2015 / \\
2014\end{array}$ & $\begin{array}{c}2015 / \\
2011\end{array}$ \\
\cline { 2 - 11 } & \multicolumn{7}{|c|}{ Абсолютные значения } & \multicolumn{7}{c|}{$\%$} \\
\hline Зерновые культуры, кг/чел. & 128 & 127 & 124 & 125 & 116 & 99,22 & 97,64 & 100,81 & 92,80 & 90,63 \\
\hline Картофель, кг/чел. & 135 & 134 & 134 & 134 & 131 & 99,26 & 100,00 & 100,00 & 97,76 & 97,04 \\
\hline $\begin{array}{l}\text { Овощи и бахчевые культуры, } \\
\text { кг/чел. }\end{array}$ & 166 & 167 & 168 & 169 & 171 & 100,60 & 100,60 & 100,60 & 101,18 & 103,01 \\
\hline $\begin{array}{l}\text { Скот и птица на убой } \\
\text { (в убойном весе), кг/чел. }\end{array}$ & 74 & 76 & 76 & 76 & 74 & 102,70 & 100,00 & 100,00 & 97,37 & 100,00 \\
\hline Молоко, кг/чел. & 201 & 201 & 203 & 201 & 197 & 100,00 & 101,00 & 99,01 & 98,01 & 98,01 \\
\hline Яйца, шт./чел. & 302 & 305 & 297 & 306 & 306 & 100,99 & 97,38 & 103,03 & 100,00 & 101,32 \\
\hline
\end{tabular}

Примечание. Составлено авторами по данным Федеральной службы государственной статистики. URL: http://www.gks.ru/bgd/regl/b16_14p/Main.htm. 
М.П. Придачук, А.П. Алмосов, Ю.В. Брехова. Продовольственная безопасность Волгоградской области

немного выросли. Объемы потребления мяса остались на прежнем уровне. Коэффициент удовлетворения физиологических потребностей населения в продовольствии рассчитаем по данным таблицы 6.

В целом потребление продуктов питания в течение последних пяти лет находилось на достаточном уровне. Лишь потребление молока населением Волгоградской области находилось на уровне ниже рекомендуемого. Среднее значение коэффициента удовлетворения физиологических потребностей населения Волгоградской области в продовольствии в течение последних пяти лет составляло 2,83 балла из 3.

На следующем этапе нашего анализа рассчитаем долю населения с доходами ниже прожиточного минимума (рис. 2).
Согласно рисунку 2, на непродолжительное время в 2012 г. произошло снижение доли населения с доходами ниже прожиточного минимума, однако уже в 2013 г. данный показатель начал расти, достигнув в 2015 г. уровня в $14,5 \%$. Несмотря на то что доля населения с доходами ниже прожиточного минимума растет, степень неравномерности распределения населения по уровню доходов изменилась незначительно (см. рис. 3).

Последний показатель, который, по нашему мнению, характеризует продовольственную безопасность региона, является удельный вес расходов на питание в структуре расходов потребителей (см. рис. 4).

В соответствии с рисунком 4 , доля доходов, которую потребители Волгоградской обла-

Коэффициент удовлетворения физиологических потребностей населения

Таблица 6 Волгоградской области в продовольствии в 2011-2015 гг.

\begin{tabular}{|l|c|c|c|c|c|c|c|c|c|c|}
\hline \multicolumn{1}{|c|}{ Показатель } & 2011 & 2012 & 2013 & 2014 & 2015 & $\begin{array}{c}2012 / \\
2011\end{array}$ & $\begin{array}{c}2013 / \\
2012\end{array}$ & $\begin{array}{c}2014 / \\
2013\end{array}$ & $\begin{array}{c}2015 / \\
2014\end{array}$ & $\begin{array}{c}2015 / \\
2011\end{array}$ \\
\hline Зерновые культуры, кг/чел. & 1,33 & 1,32 & 1,29 & 1,30 & 1,21 & 3 & 3 & 3 & 3 & 3 \\
\hline Картофель, кг/чел. & 1,50 & 1,49 & 1,49 & 1,49 & 1,46 & 3 & 3 & 3 & 3 & 3 \\
\hline $\begin{array}{l}\text { Овощи и бахчевые культуры, } \\
\text { кгчел. }\end{array}$ & 1,19 & 1,19 & 1,20 & 1,21 & 1,22 & 3 & 3 & 3 & 3 & 3 \\
\hline $\begin{array}{l}\text { Скот и птица на убой (в убойном } \\
\text { весе), кг/чел. }\end{array}$ & 1,03 & 1,06 & 1,06 & 1,06 & 1,03 & 3 & 3 & 3 & 3 & 3 \\
\hline Молоко, кг/чел. & 0,62 & 0,62 & 0,62 & 0,62 & 0,61 & 2 & 2 & 2 & 2 & 2 \\
\hline Яйца, шт./чел. & 1,16 & 1,17 & 1,14 & 1,18 & 1,18 & 3 & 3 & 3 & 3 & 3 \\
\hline $\begin{array}{l}\text { Среднее значение коэффициента удовлетворения физиологических по- } \\
\text { требностей населения Волгоградской области в продовольствии }\end{array}$ & 2,83 & 2,83 & 2,83 & 2,83 & 2,83 \\
\hline
\end{tabular}

Примечание. Составлено авторами по данным Федеральной службы государственной статистики. URL: http://www.gks.ru/bgd/regl/b16_14p/Main.htm.

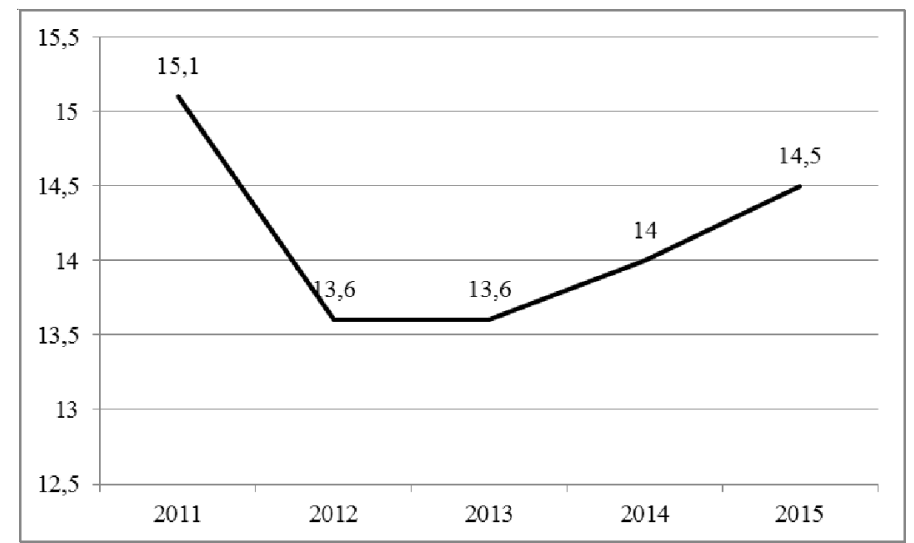

Рис. 2. Доля населения Волгоградской области с доходами ниже прожиточного минимума в 2011-2015 гг., \%

Примечание. Составлено авторами по данным Федеральной службы государственной статистики. URL: http://www.gks.ru/bgd/regl/b16_14p/Main.htm. 


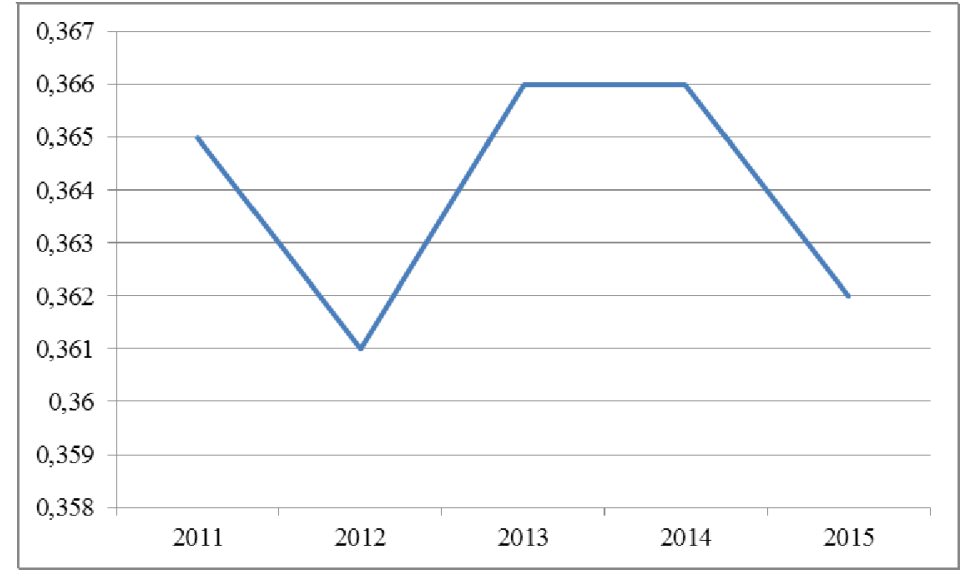

Рис. 3. Степень неравномерности распределения населения Волгоградской области по уровню доходов в 2011-2015 гг., \%

Примечание. Составлено авторами по данным Федеральной службы государственной статистики. URL: http://www.gks.ru/bgd/regl/b16_14p/Main.htm.

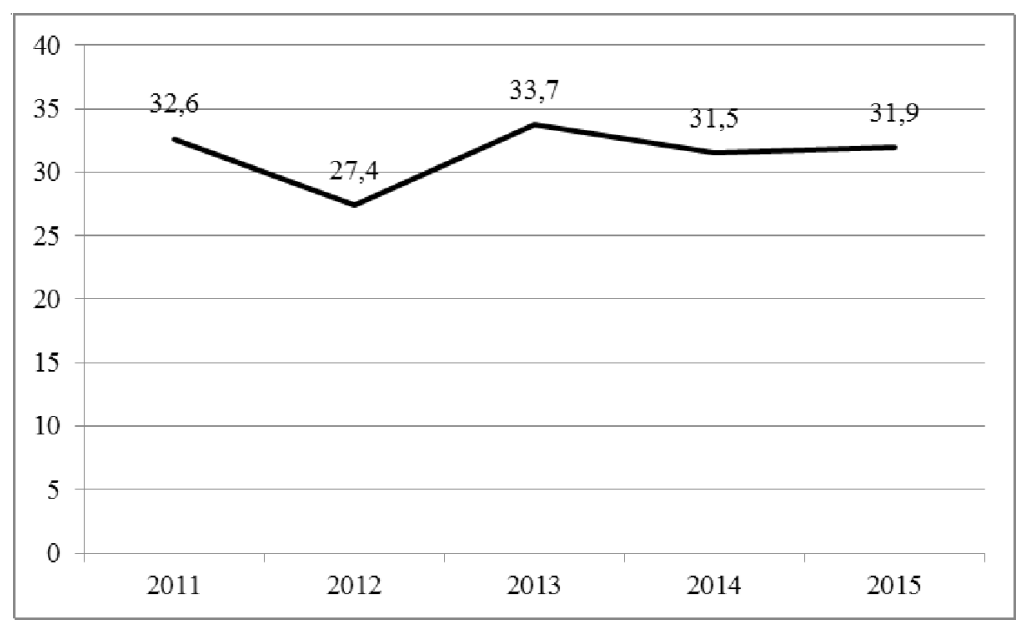

Рис. 4. Удельный вес расходов на питание в структуре расходов потребителей Волгоградской области в 2011-2015 гг., \%

Примечание. Составлено авторами по данным Федеральной службы государственной статистики. URL: http://www.gks.ru/bgd/regl/b16_14p/Main.htm.

сти тратили на питание в течение 5 лет, оставалась практически неизменной и колебалась от 32,6 \% до $31,9 \%$, что в целом является хорошим показателем. После анализа всех показателей рассчитаем общее количество баллов и оценим уровень продовольственной безопасности Волгоградской области (см. табл. 7).

По результатам анализа продовольственной безопасности Волгоградской области можно сделать вывод о том, что в течение 20112015 гг. регион характеризовался высоким ее уровнем, равным значению 12,55 балла.

Как показывает анализ, наименышим уровнем развития в регионе отличается мясной ком- плекс. Именно данный комплекс не позволяет выйти региону на более высокий уровень продовольственной безопасности. Для консолидации мясной промышленности и ее развития, на наш взгляд, необходимо организовать мясной кластер на территории Волгоградской области.

Возможность создания и развития территориально-производственных кластеров в России предусмотрено Концепцией долгосрочного социально-экономического развития Российской Федерации. Такая кластеризация предусмотрена с целью реализации конкурентных преимуществ регионов и развития их инновационного потенциала. 
М.П. Придачук, А.П. Алмосов, Ю.В. Брехова. Продовольственная безопасность Волгоградской области

Таблица 7

Оценка общего уровня продовольственной безопасности Волгоградской области в 2011-2015 гг., баллы

\begin{tabular}{|l|c|c|c|c|c|}
\hline \multicolumn{1}{|c|}{ Показатель } & 2011 & 2012 & 2013 & 2014 & 2015 \\
\hline Коэффициент самообеспеченности & 2,71 & 2,71 & 2,71 & 2,71 & 2,71 \\
\hline Коэффициент фактического потребления продовольствия & 2,83 & 2,83 & 2,83 & 2,83 & 2,83 \\
\hline $\begin{array}{l}\text { Доля населения с доходами ниже установленной величины } \\
\text { прожиточного минимума }\end{array}$ & 3 & 3 & 3 & 3 & 3 \\
\hline $\begin{array}{l}\text { Удельный вес расходов на питание в структуре расходов } \\
\text { потребителей }\end{array}$ & 2 & 2 & 2 & 2 & 2 \\
\hline $\begin{array}{l}\text { Степень неравномерности распределения населения по } \\
\text { уровню доходов }\end{array}$ & 2 & 2 & 2 & 2 & 2 \\
\hline Сумма баллов & 12,55 & 12,55 & 12,55 & 12,55 & 12,55 \\
\hline Процент от максимального количества баллов & 0,84 & 0,84 & 0,84 & 0,84 & 0,84 \\
\hline
\end{tabular}

Примечание. Составлено авторами по данным Федеральной службы государственной статистики. URL: http://www.gks.ru/bgd/regl/b16_14p/Main.htm.

Рекомендация по созданию на территории Волгоградской области мясного кластера согласуется с Прогнозом долгосрочного социально-экономического развития Российской Федерации на период до 2020 г., в соответствии с которым в Южном федеральном округе должен быть сформирован мощный агропромышленный кластер, способный обеспечить отечественный и зарубежный рынки широким перечнем сельскохозяйственной продукции. Формирование кластеров предусмотрено также и Стратегией инновационного развития Российской Федерации на период до 2020 года. Данный документ предполагает привлечение государственных органов власти и местного самоуправления к процессу создания кластеров в том случае, если они реализуют инновационный потенциал. Привлечение органов власти к данному процессу подразумевает не только обеспечение административного регулирования и поддержки, но и финансирование проектов по созданию кластеров и предприятий, которые его формируют. Такое финансирование может осуществляться за счет передачи бюджетных средств из федерального бюджета в бюджеты нижестоящих уровней для точечного субсидирования сельскохозяйственных предприятий, а также в рамках целевых программ по развитию инновационных региональных кластеров.

Исходя из перечня первоочередных мероприятий, которые следует осуществить при организации мясного кластера, можно пред- положить, что его создание на территории Волгоградской области приведет к развитию других секторов экономики региона.

Предлагаемую организационную структуру кластера представим на рисунке 5 .

К предполагаемым участникам мясного кластера Волгоградской области следует отнести:

- региональные предприятия из отрасли сельского хозяйства;

- мясоперерабатывающие предприятия;

- органы государственной власти региона;

- образовательные и научно-исследовательские учреждения;

- поставщиков технологического оборудования и потребителей сельскохозяйственной продукции;

- региональные торговые предприятия и финансово-кредитные учреждения;

- общественные организации;

- координационный и информационноаналитический центры;

- инновационный центр.

Научно-исследовательскую поддержку развития кластера могут обеспечить следующие региональные и общероссийские учреждения:

- Волгоградский институт управления РАНХиГС;

- Волгоградский государственный аграрный университет;

- Волгоградский государственный университет; 


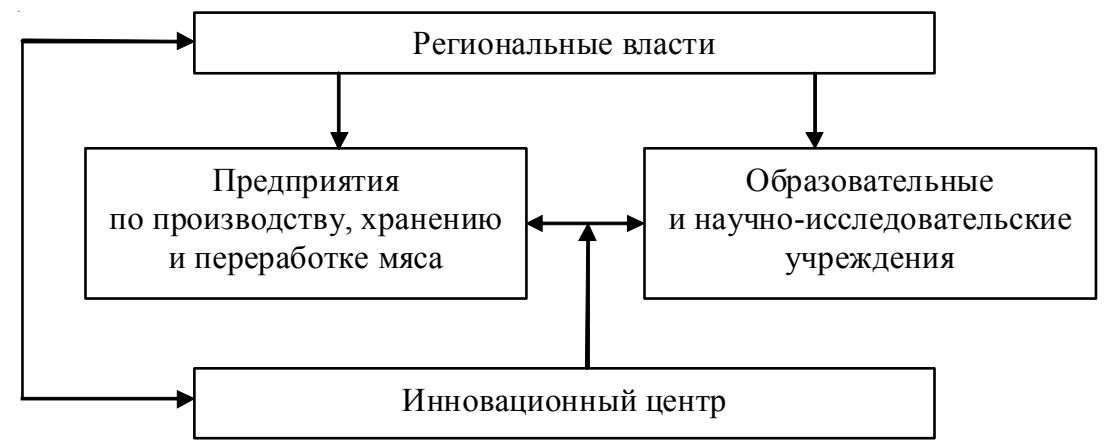

Рис. 5. Организационная структура мясного кластера Волгоградской области

Примечание. Составлено авторами.

- Всероссийский научно-исследовательский институт мясного скотоводства РАСХН (ВНИИМС);

- Всероссийский научно-исследовательский институт мясной промышленности имени В.М. Горбатова.

Привлечение к функционированию кластера перечисленных учреждений позволит аккумулировать новейшие научные разработки в открытом инновационном центре. Из центра данные инновации могут на безвозмездной основе передаваться в сельскохозяйственные предприятия кластера.

Положительный эффект от развития кластера приведет к следующим сопутствующим положительным последствиям:

- повышение конкуренции между поставщиками оборудования для мясной продукции снизит цены и повысит его качество для предприятий-покупателей из отрасли сельского хозяйства;

- повышенный спрос на инновации повысит масштаб и качество инновационных разработок научно-исследовательскими и образовательными учреждениями;

- финансово-кредитные организации диверсифицируют программы финансирования для предприятий мясного кластера;

- предприятия, являющиеся ядром мясного кластера, перейдут на инновационные методы производства, что увеличит объемы производства мясной продукции и снизит издержки по ее производству.

Подводя итоги, еще раз отметим, что Волгоградская область является индустриально-аграрным регионом, в результате чего около 78 \% общей площади региона - земли сельскохозяйственного назначения. По результа- там анализа продовольственной безопасности Волгоградской области можно сделать вывод о том, что в течение 2011-2015 гг. регион характеризовался высоким ее уровнем, равным значению 12,55 балла. В качестве рекомендации предлагается создание мясного кластера, который будет включать в себя сельскохозяйственные предприятия, образовательные и научно-исследовательские учреждения, предприятия и организации инфраструктуры. Целью создания кластера является развитие кооперации между его элементами и повышение эффективности деятельности за счет инноваций в производстве.

\section{СПИСОК ЛИТЕРАТУРЫ}

1. Антамошкина, Е. Н. Интегральная оценка продовольственной безопасности регионов ЮФО / Е. Н. Антамошкина // Вестник Волгоградского государственного университета. Серия 3: Экономика. Экология. - 2014. - № 1 (24). - C. 6-16. - DOI: http://dx.doi.org/10.15688/jvolsu3.2014.1.1.

2. Волох, В. П. Доктрина продовольственной безопасности РФ / В. П. Волох // ЭКОС-информ. 2013. - № 11. - С. 10-24.

3. Терентьев, Ю. Методика определения уровня продовольственной безопасности / Ю. Терентьев. - Электрон. текстовые дан. - Режим доступа: http://ut55.blogspot.com/2010/10/blogpost_16.html. Загл. с экрана.

\section{REFERENCES}

1. Antamoshkina E.N. Integralnaya otsenka prodovolstvennoy bezopasnosti regionov YuFO [Integrated Assessment of Food Security in the Regions of the SFD]. Vestnik Volgogradskogo gosudarstvennogo universiteta. Seriya 3: Ekonomika. Ekologiya [Science 
М.П. Придачук, А.П. Алмосов, Ю.В. Брехова. Продовольственная безопасность Волгоградской области

Journal of Volgograd State University. Global Economic System], 2014, no. 1 (24), pp. 6-16.

2. Volokh V.P. Doktrina prodovolstvennoy bezopasnosti RF [The Doctrine of Food Security of Russia]. EKOS-inform, 2013, no. 11, pp.10-24.
3. Terentyev Yu. Metodika opredeleniya urovnya prodovolstvennoy bezopasnosti [The Method of Determining the Level of Food Security]. URL: http:// ut55.blogspot.com/2010/10/blog-post_16.html. (accessed August 20, 2017).

\section{Information about the Authors}

Maksim P. Pridachuk, Doctor of Sciences (Economics), Associate Professor, Deputy Director of Volgograd Institute of Management - Branch of Russian Presidential Academy of National Economy and Public Administration, Gagarina St., 8, 400131 Volgograd, Russian Federation, prorector.nauka@vlgr.ranepa.ru.

Aleksandr P. Almosov, Candidate of Sciences (Economics), Associate Professor, Dean of Faculty of State and Municipal Management, Volgograd Institute of Management - Branch of Russian Presidential Academy of National Economy and Public Administration, Gertsena St., 10, 400078 Volgograd, Russian Federation, vsamol@yandex.ru.

Yuliya V. Brekhova, Candidate of Sciences (Economics), Associate Professor, Head of Department of Economics and Finance, Volgograd Institute of Management - Branch of Russian Presidential Academy of National Economy and Public Administration, Gertsena St., 10, 400078 Volgograd, Russian Federation, brechova7@mail.ru.

\section{Информация об авторах}

Максим Петрович Придачук, доктор экономических наук, доцент, заместитель директора, Волгоградский институт управления - филиал РАНХиГС, ул. Гагарина, 8, 400131 г. Волгоград, Российская Федерация, prorector.nauka@vlgr.ranepa.ru.

Александр Павлович Алмосов, кандидат экономических наук, доцент, декан факультета государственного и муниципального управления, Волгоградский институт управления - филиал РАНХиГС, ул. Герцена, 10, 400078 г. Волгоград, Российская Федерация, vsamol@yandex.ru.

Юлия Викторовна Брехова, кандидат экономических наук, доцент, заведующая кафедрой экономики и финансов, Волгоградский институт управления - филиал РАНХиГС, ул. Герцена, 10, 400078 г. Волгоград, Российская Федерация, brechova7@mail.ru. 